\title{
NOTES UPON CONTINENTAL LEGAL LITERATURE
}

When the Gothic peasant, Uprauda,-in English, The Upright,- -ascended the Imperial throne in 527 , he assumed the equivalent appellation of Justinian, and almost immediately entered upon his ambitious scheme for the revision and codification of the law. In 530, when he issued his instructions to Tribonian for the preparation of the Digest, .he took pains to warn in advance the "jurisperiti" of his Empire not to add their commentaries to it, and thus confound the work with their verbosity, since, as he said, the whole law is well nigh confused by the contrary opinions of its interpreters. ${ }^{1}$

Three years later the finished product of the Commissioners was declared to be in force, and Justinian repeated his command with even greater emphasis, ${ }^{2}$ and in the Code these solemn warnings were reproduced with stringent pen.alties. ${ }^{3}$

Tribonian and his fellows must have been startled by 'the imperial assumption, that their compilation, for which Justinian naturally took to himself much of the credit, was the final word of legal science, and the threats of legal proceedings against the commentators, and of the destruction of their works, must have amused the lawyers of the day, if they possessed any sense of humor whatever. They were doubtless as long suffering as we, their humble successors, are today, but even the worm will turn, and the command of an imperial autocrat himself cannot cure a lawyer of the cacoethes scribendi, who has access to pen, ink, and paper, any more than the touch of a modern king can heal the scrofulous. Justinian even lived to see the day, we are told, when the commentators flourished their scrolls before his very eyes with impunity, and all through the middle ages these busy toilers lectured and wrote and disputed, eluci-

${ }^{1}$ Const. De Conceptione Digestorum.

${ }^{2}$ Const. De Confirmatione Digestorum.

${ }^{3}$ De veteri jure enucleando Cod. I, I7.22. 
dating, said their detractors, what was clear, and obscuring. what before was merely doubtful; as it was then, is now and ever shall bè, world without end.

The labors of the Glossators, so called, culminated in the great gloss of Accursius (I2OI-I279), so highly esteemed, that it was called the Perpetual Gloss, and superseded all others. Justinian, if his shade were cognizant of what had gone on in his absence, would have applauded Rabelais, who makes Pantagruel say, in comparing the Corpus Juris to an elegant garment, that "there are no Books in the World so fine, so ornate, so elegant, as the Texts of the Pandects, but the bordering of them, to wit, the Gloss of Accursius, is so. filthy, scandalous, and mean, that it is nothing but Dirt and Villainy." 4 Legal opinion however stood valiantly behind the Gloss, notwithstanding its critics; thus de Caevellos, a very much later writer ${ }^{5}$ says, "that the Gloss is the idol of the Advocates, and it is better to stand by the Gloss. than to form new opinions."

Nevertheless, the Perpetual Gloss proved only temporary, and the Post-Glossators, or Commentators, led by Bartolus, not being content with it, poured forth a fresh mass of material for the busy practitioners. Decried as they have been, these old Glossators and Commentators, nevertheless, did much to further the scientific study of the Roman law; they established the text of the Corpus Juris, they strengthened its authority and by their exegesis assisted the writers. of subsequent times to understand it. Their work was analytical rather than historical or comparative; in fact, they had not the necessary apparatus for accurate historical: or comparative investigation, nor did they realize the importance of such studies; so that their commentaries naturally. included much that can now be seen to be either erroneous, confusing or useless.

${ }^{4}$ Book ii, ch. 5. Yet afterwards in Book iii, ch. 44, Rabelais in the person of Pantagruel severely criticizes the Corpus Juris, and Tribonian as responsible for it; and in Book ii, ch. 30 , Epistemon on his return from Hell recounted the employments of the Damned who on Earth had been men of some importance in their day. He found Justinian occupied as a maker of Children's Rattles; useless toys producing sound without sense.

'Speculum Aureum Pref. 65, Rome, 1609. 
For the present we shall not speak further of the work of these men, but pass on to the more immediate subject of this paper, the later development of the continental law, especially in Italy. In that country, the Roman law of Justinian always held sway; it was the Jus Commune, as distinguished from the law, which obtained in the various kingdoms, principalities and republics, so called, of which Italy, geographically speaking, was composed, where the statutes and local customs merely modified but did not displant the law of Rome. For there was not in Italy any "reception" so called of the Roman law, which superseded the local laws founded upon ancient custom; there was no "reception" because it had always been received, and while the Renaissance was not without its effect here as everywhere, especially in France, it merely stimulated the development of the law and directed its growth. Of far greater influence was the coeval invention of the art of printing, by which the law writers of the sixteenth century, and afterwards, were enabled to publish a mass of legal literature, which in its volume was simply appalling.

Italy of all countries was the country of the law, and no where else was the science so popular and so developed; its votaries, indeed, followed the methods laid down by the earlier commentators, but they extended the researches of their predecessors, and applied established principles to more modern conditions of politics and society. This state of things continued for centuries, and I propose to examine the lawyers' armamentarium from which they drew their arguments and upon which the courts grounded their decisions, up to the very recent times. ${ }^{6}$

I. First, of course, was the immortal Corpus Juris of Justinian, comprising the Institutes, the Digest or Pandects,

-Among the valuable bibliographies are those of Augustinus Fontana with its continuation, seven parts, Parma, I688-1694; Martinus Lipenius, four vols., Leipsic, I757-1789. The Bibliotheca Juris of $B$ B. Struvius passed through many editions.

Guidus Panzirolus compiled an interesting legal biography. The edition of C. G. Hoffman is Leipsic, 172I. The works of Fichardus, Mantua, de Gazalupis, Cotta, Morpha and Gentilis are less important. Tiraboschi and vol. 4 of de Savigny are most generally used. 
the Codex and the Novels; these were always the foundatiom of the law and its supreme authority. Any applicable text was decisive, and if no text could be found exactly in point inferences more or less direct, and not infrequently very strained, were drawn from others, just as the theologians and the ecclesiastical lawyers performed similar feats in biblical exegesis. Their method of reasoning was very much the same, and, indeed, the Justinianean texts were considered as almost inspired. Every lawyer was of necessity so familiar with the fundamental texts, that the customary method of citation was by the initial words of the paragraph or law, referring merely in addition to the Title. The tax upon the memory must have been enormous, as any one will realize who has endeavored to verify the references to the Digest and Code, which are contained in the books that were based upon them. ${ }^{7}$ Many of the decisions and rescripts. embodied in the Digest date back to the beginning of the Christian era, and when we reflect that they continued to be cited all through these centuries, we gain some idea of the continuity and stability of the system. The history of the common law discloses no parallel.

2. Next in importance to the Corpus Juris itself, if not of equal authority, was the Gloss to which reference has. been made. The later editions of the Corpus Juris contained not merely the Gloss, but also notes taken from the subsequent writers, constituting alone an enormous and unwieldy library of the law. The editions were very numerous, but perhaps among the best may be said to be that of a Parta \& Vicentius, printed at Lyons, 1558, and becter still that of Cardon \& Cavellat, (Lyons, 1627), a magnificent specimen of tynography, which can only be described by Dominie Sampson's phrase "prodigious." To quote John Hill Burton; "These are the terrible folios of the scholastic divines, the civilians and the canonists, their majestic stream of central part, overflowing with rivulets of marginal notes, sedgy with citations. Compared with these, all the recent efforts

'Later, indices of the titles were published, as in the Modus Legendi Abbreviaturas, Venice, 1572. 
of our degenerate days seem the work of Pygmies; and for any of us to profess to read all that some of these indomitable giants wrote, would seem an audacious undertaking."

3. Next followed the Post-Glossators, whose works are staggering in volume. Those who are probably the most frequently cited were Bartolus (I3I4-I357); Baldus de Ubaldis, (I327-I400); Paulus Castrensis, (circ. I390, d. I44I); Jason de Mayno, (circ. I345); Alciatus, middle of the sixteenth century, and Philippus Decius, (I454-I535).8 The Venice Edition of Bartolus, 1570, republished in 1585 , is in eleven volumes, that of Baldus in $1572-1586$ is in nine volumes; those of Paulus Castrensis in I593 (eight volumes) and Jason de Mayno, in I579-98 (nine volumes), were all published apud Juntas; and all these, enriched with numerous editorial notes, continued in use up to recent years. They are even now valuable in research, though by no means easy reading, especially in those editions that retain the typographical contractions, which continued when printing supplanted manuscript. Some of the comments are so succinct, that they seem to have been merely the notes of the lecturer.

4. Parallel with the Corpus Juris Civilis was the Corpus Juris Canonici, consisting of the Decretum of Gratian, the Decretals of Gregory IX, the Liber Sextus, the Clementine Constitutions, the Extravagantes of John XXII, and the Extravagantes Communes, constituting an enormous bulk of law, which was glossed and commented upon like the Corpus Juris Civilis: Probably the best edition is that of Cardon \& Cavellat (Lyons, I624), the publishers of the glossed edition of the Corpus Juris Civilis, while the modern textus receptus is that of Friedberg (Leipsic, 1879-8I). A convenient annotated edition is that of Lancellottus, (Lyons, I759-60), who added his Institutiones Juris Canonici.

8The volume entitled Great Jurists of the World, in the Continental Legal History series, contains in the chapters on Bartolus and Alciatus an interesting account of them, while Sidney Woolf's Bartolus of Sassoferrato may be referred to. The limits of this article do not permit the writer to give any account of these and other writers mentioned. 
While the Canonical law was not, strictly speaking, authority in the secular courts, yet it was frequently used for illustration, and its principles were followed when the Civil law was inadequate, just as our own common law will occasionally borrow from the Roman or the Civil law, but to a much greater extent. On the other hand, when the matter in controversy was defined by the Civil law, and not by the Canon law, the Civil law was followed in the ecclesiastical courts. Even in the secular courts, if the question concerned some matter of conscience or sin, the Canon law was followed.

The Commentators on ecclesiastical law were almost as numerous as those upon the Civil law, and even more difficult and tedious to read.

5. The Jus Commune as found in the Corpus Juris and elaborated by the glossators and commentators, was, of course, modified or altered by the statute law of the several countries, and by municipal ordinances, just as the English Common Law, which was inherited from England, still serves as the substratum of the law in many of our States and in other countries settled by the British. So also, to speak only of Italy, every independent or quasi-independent state or city had naturally its own special laws and bannimenta. The treatise of George Bowyer on the Statutes of the cities of Italy gives an interesting account of them, especially those of Florence and Genoa. The Papal Bulls and Constitutions collected in the Magnum Bullarium Romanum with its continuation comprise seven volumes up to I726, and the Bulls from Clement $X$ to Pius VI are in sixteen volumes, and there are many other collections. The commentary on the earlier Bulls by J. A. Novarius, Rome, I677, was often cited, The Statutes of Rome were edited by Galganetti (Rome, I6II); and F. M. Constantinus published in 1773 his Observationes ad varia capita. ${ }^{9}$ The tenacity, however, with which the Continental countries adhered throughout all statutory changes to the foundation of the law, in the Corpus Juris of Justinian is very remark- 
able, and produced a wonderful catholicity of jurisprudence, which must have exerted a most powerful influence. Thus some of the noted criminalists were Carpzovius, the Saxon; Clarus, the Italian; Gomezius, the Spaniard; Damhouderius, the Belgian; and Matthaeus, the Dutchman. These writers and others like them proceeded from the general Roman law to that of their own country, exhibiting the changes made by their own legislation and decisions.

6. The Jus Commune was likewise modified by the local usages and customs, which, originally unwritten, were frequently compiled and revised in statutory form. The incursions of the Goths profoundly affected the law in France and in the north of Italy, while Naples in the south derived its early customs from Greece. ${ }^{10}$

7. Tractatus, or treatises upon the Practice or Theory of the law or some branch of it, either Civil or Criminal or Canonical. Their value as authority depended, of course, upon the reputation of the writers, and many of them were held in high esteem, being cited and relied upon by counsel and courts, just as in our own day we rely on the opinions of such writers as Sugden, Jarman, Story, Benjamin and Pollock.11 Sometimes these treatises bore titles intended to be attractive, as the Sylva Communium Opinionum of Vivius, the Sylva Nuptialis of Nevizzanus, and the Pugna Doctorum of Danza. Speculum in the sense of a handbook was often used in various countries and languages. Its connection with the literal mirror is obvious, the statement of the law appearing in the book as in a mirrow, e.g., the Speculum Aureum of de Caevallos, the Sachsenpiegel, and in England, the Mirror of Justices. ${ }^{12}$

The statutes of Eugubium (Gobbio), an ancient city of Umbria were annotated by Antonius Conciolus, Gerona, I685. As to local statutes, especially those in force in the Ecclesiastical State, see Card. de Luca, ad constitutionem Innocent XI de statuaribus successionibus.

${ }^{10}$ Many books were compiled on local customs, e. g., Bartholomaeus a Chassanaeo, Commentaria ad consuetudines Ducatus Burgundiae, Frankfort, I574; Consuetudines Neapolitanae cum glossis, Naples, 1546.

"These tractatus are almost innumerable, some are quite comprehensive, but many treat only of a very narrow subject. $e$. g., Didacus Narbona, de Aetate; Polydorus Ripa, de Nocturno Tempore; Franciscus Molinus, de Ritu Nuptiarum. \& Rev. I57.

"See Article on "Speculum and Mirror" by James Williams, 26 Law Mag. 
8. Sometimes the Tractatus took the form of commentaries on various codes of law; Jo. Dominicus Raynaldus, for example, wrote his Observationes Criminales Civiles et Mixtae upon the Bannimenta or Ordinances of Bologna, and thus produced a very complete treatise. Gomezius compiled his treatise on the criminal law as a commentary on the Leges Tauri, the laws promulgated in 1505 by the Cortes at Toro, considered in Spain as the vade mecum of lawyers and judges. De Zaulis likewise wrote on the Statutes of Faenza; Marius Muta, on the Capitula of the Kingdom of Sicily; Matthias de Afflictis, on the Constitutions of the Sicilies and Naples. Angelus Aretinus (de Gambilionibus) wrote his de Maleficiis in the curious form of a commentary upon the inquisition and sentences in a trial for homicide at Bologna in 1437. Antonius Matthaeus de Criminibus is a commentary on the $47^{\text {th }}$ and 48 th books of the Digest. Petrus Follerius put his Practica Criminalis in the form of a dialogue, perhaps we may say a trialogue, in which the Fiscus, the Inquisitus and the Judex sustain the conversational parts.

9. Quaestiones. These were discussions of particular points or questions of law, including. suppositious or moot cases; and often they covered the whole field of the subject. ${ }^{13}$ Sometimes such works were called by their author, Consclusiones (e. g., Berlichius); or Resolutiones (e. g., Caballus and Conciolus); Sententiae (e. g., Clarus); Observationes (e.g., Gaill); or Disceptationes Forenses (Gratianus). Others were called Consultationes, Interpretationes, Memorabilia \&c. Gratianus says he prefers Disceptatio, because it means Cognitio veritatis.

Io. Consilia or Responsa. These were arguments made or opinions given by counsel in cases arising in their practice. It seems very strange to us, that the mere arguments of counsel in one case should be quoted as authority in another, and yet in all the continental legal literature the consilia of distinguished lawyers are cited with about the beside.

${ }^{13}$ The Quaestiones of Farinacius include the entire criminal law and much 
same frequency and as carrying the same weight as the Quaestiones and Decisiones. It may be suggested as an explanation, that counsel were regarded as the successors of the old Jurisconsults to whose opinions Augustus gave official authority; Dig. I.2.35. 49. cited by Roby in his Introduction to Justinian's Digest 102, who says "Whether such opinions were obtained by the parties and presented by them to the judge, or obtained by the judge himself; whether all were consulted as a body (which is not probable) or any one or more as the parties chose, we do not know." As Dr. Muirhead points out; ${ }^{14}$ the judges were then private citizens and not necessarily learned in the law. They were, therefore, asking for and acting on the opinion of experts, and the patented Jurisconsults were like King's Counsel, bound to give their professional assistance and counsel to the sovereign power. ${ }^{15}$ According to Muirhead, this practice expired in the third century, yet it may be that in a similar fashion counsel in these later times, who gave opinions to their clients, or argued in their behalf, were regarded as, strictly speaking, officers of the Court assisting it in the discharge of judicial duty. When, therefore, counsel in argument laid down a statement of the law, although it was enunciated with special reference to his client's case, he was considered to have given a general opinion, that should apply in all similar cases. Indeed the published consilia were very often formal considered judgments prepared at the request of the Court or Sovereign. We are reminded of the Merchant of Venice, where the Duke sends to Bellario, a distinguished Doctor, for his opinion or consilium, and he, being unable to come by reason of illness, sends as his substitute Balthazar, or rather Portia, who is thus to the glory of her sex, enabled to carry off undying laurels. ${ }^{16}$

\footnotetext{
14Historical Introduction to the Private Law of Rome. 2nd Edition by Goudy p. 292.

${ }_{15}$ See recent article by W. S. Holdsworth, The Rise of the order of King's Counsel, 36 L. Q. R. 212. King's Counsel were paid a salary of $£_{40}$ until (as I have read) the office was abolished and Counselorship became merely a professional grade in 1830, Campbell's Lives of the Chancellors in the Life of Lord Bacon; 9 Foss's Judges, p. 66.

"See John T. Doyle on "Shakespeare's Law, The case of Shylock" in Appendix to Furness's Variorum edition.
} 
Mascardus, indeed, sagely remarks upon the practice of citing consilia (in special reference to the proof of custom) ${ }^{17}$ that "More credit should be given to a Doctor in his lectures about custom, than in his Consilia, for Doctors in writing strive for the truth, more than they do in advising, for in lecturing bias and desire for money are absent, which dominate the minds of men, particularly Doctors in these times of ours. If there is any one who does not see this, I think he sees nothing, for this is so apparent as to need no further proof."

Judge Wessels of South Africa in his admirable History of the Roman-Dutch law, p. 24I, gives a most interesting account of the old Consultatien in Holland, as having a foremost place in the legal literature of that country, where they played a very important part in the development of the Roman-Dutch law. It would seem, however, that these Consultatien did not have there as great authority as the Consilia and Responsa certainly possessed in Italy and elsewhere on the Continent, where the popular collections of Consilia were often republished like the Quaestiones and Decisiones, and edited with "notes," "observationes" and "additions." Sometimes these notes by distinguished lawyers obtained even greater authority than the originals.18

II. Decisiones or Vota. These were decisions or judgments of the courts in actual cases, and the best reports generally included a statement of the facts of the case, and sometimes the arguments of counsel as well. The decisions might be selected from several jurisdictions, or be merely those of a particular court. Thus we have the decisions of Berlichius (Decisiones Aureae, cases in the German Courts, especially Saxony); Farinacius (Rome); Muta (Sicily); Chartarius (Milan); Dynus (Umbrian Courts); Surdus (Mantua); Grammaticus, Capycius and Capycius Latro, de

${ }^{17}$ de Probationibus, Conclus. 426, n. 26.

18. Almost every lawyer of large practice published bulky Consilia. Among those frequently cited are Alexander Tartagnus de Imola; (I28I Consilia); Bart. Bertazzolius, (560 Consilia); Bursatus, (1561 Consilia); the Soccini; Corneus (ra I9 Consilia); Cravetta, (rooo Consilia); P. P. Parisius, (5 ro Consilia); Farinacius; Jac. Menochius (40o Consilia), and very many others. 
Franchis, Sanfelicius, Vivius and de Afflictis (Naples); Riccius (Naples ecclesiastical); de Cortiada and de Caldero (Catalonia); Nicolaus Boerius (Parlement of Bordeaux); Marius Giurba (Messina); J. A. Marta, (Pisa) and Antonius Thesaurus (Piedmont). The decisions of the Sacred Roman Rota from $\mathrm{I} 55^{8}$ to $\mathrm{I} 683$ were published in nineteen volumes as the Decisiones Recentiores. The Decisiones Novissimae Diversorum Auditorum embracing the latter period of the r6th century were cited as Decis. Divers.; the Decisiones Nuperrimae were published in nine volumes, (Rome, I75I63), and there were many other collections, the volumes sometimes including only the decisions of a single Judge or Auditor of the Rota. ${ }^{19}$ Matthaeu et Sanz published the decisions of the Spanish Supreme Aula and Senate of the New World as his Tractatus de Re Criminali. Marta compiled an ambitious but disappointing Digesta Novissima Totius, or Universal Digest of Decisions. The Conclusiones of Cardinal Tuschus is an enormous digest arranged alphabetically in eight volumes.

It is generally supposed that the Civilians reposed little reliance upon judicial decisions as authority, and that this is one of the principal distinctions between the systems of the Civil and the Common Law. Of course, in France since the Code, articles 5 and I35I being particularly applicable, this appears to be true, and so in other civil law countries, which have adopted this principle of the Code Napoleon, although even in France the value of decisions as authority is the subject of much discussion. But in Italy up to the last century at least, however it may be now, decisions were quoted in argument and in other decisions very much as they are now with us. The judgments of the Sacred Roman Rota especially were regarded with profound respect; the decisions of the Courts of the various Italian States and those of Spain were held in high esteem, as were also to a consider-

19These collections were often enormous. The decisiones of Josephus Molines, Rome, I726, are in eight folio volumes. Frequently the decisions of a single judge exceeded a thousand. 
able extent those of the French and even of the German courts. Naturally, the Roman Rota enjoyed the highest prestige, its ecclesiastical jurisdiction being universal and its secular jurisdiction being supreme in the States of the Church, so its judgments were regarded as magistrales or authoritative. Conciolus ${ }^{20}$ says that it is impious to doubt them, and de Caevallos ${ }^{21}$ says they were of greater authority than the communis opinio of the Doctors. ${ }^{22}$

12. This communis opinio Doctorum, the common or general opinion of the Jurists, was invoked in all doubtful cases, just as our courts are apt to follow the "weight of authority." This doctrine is based upon the effort to extract from an unwieldy mass of inconsistent opinions or decisions some general rule, and to bring about in this way uniformity in the law. Some authors even determined doubtful points according to the opinio communior. Thus Cyriacus, ${ }^{23}$ enumerates forty-two authorities on one side of the question (one of inheritance), and fifty-eight on the other side, and says, that from this recital of the authorities it appears that the latter opinion is the more common. De Caevallos of Toledo in his Speculum Aureum collected numerous contested questions, where the proponents of each side claimed to be supported by the Communis Opinio. But reliance upon the general opinion of the profession is not confined to the Civil law. Sir Edward Coke held it to be good authority, and other references may be found in Ram on Judgments, p. I2.

I3. Texts from the Bible were very often cited as authority not only by the Canonical but also by the Civilian writers, and arguments and decisions were copiously adorned with illustrations from the writings of the ancient philosophers and poets, especially Aristotle, Plato, Ovid, Martial, Virgil

${ }^{20}$ Alleg. 95 n. 33 and Alleg. 97 n. 8.

21Speculum Aureum, Pref. 26.

${ }^{22}$ As to the Roman Rota, see Domenico Bernino, Il tribunale dell' S. Rota Romana, Rome, I7I7, It was styled "Totius Christiani Orbis Supremum Tribunal," and its judges were eminent ecclesiastics of divers nationalities.

${ }^{23}$ Controversiae Forenses. 353 . 
and Horace. It is only necessary to refer to this without examining its extent in detail. ${ }^{24}$

I4. Finally we may add as a fourteenth source of authority, the legal maxims, Regulae Juris or Brocardia of which the classical and medieval writers were very fond. The Digest 50, I7 De diversis regulis contains many; and a similar collection is appended to the Sext. V. 12, De regulis juris. The Axiomata of Augustinus Barbosa, (the forerunner of Broom) reached a sixth edition in 1737 , and many maxims are explained by Antonius Gabrielus, Communes Conclusiones Book 6.25 They have been used, however, by English judges and lawyers as well, and many are now in common use. Coke's writings abound with them, and I suspect a goodly number were coined in his private mint. These short pithy sentences, intended to express or emphasize a general principle of law, like popular proverbs in common conversation, may legitimately be used, with proper caution, to point the argument and adorn the opinion, for in many cases they do really present general rules of law or public policy in a crystallized form. Professor Goudy well says, ${ }^{26}$ that brocards or maxims have a certain utility in concentrating the ideas and stimulating the memory, and the reader may be referred to Ram on Judgments, ${ }^{27}$ for some interesting comments on the subject.

Having thus enumerated our fourteen sources of Continental law (our fourteen points so to speak) we observe, that in his examination of the legal armamentarium of the Civil lawyers, the modern critic cannot fail to be struck with the painstaking industry of these prolific writers in the collection of precedents, and the minuteness of detail with which every phase of the subject is exhausted. ${ }^{28}$ The

${ }^{2}$ Here we may mention Mosaicarum et Romanorum Legum Collatio, which according to its more recent editor, M. Hyamson (1913) was prepared for the instruction of Christian clerics, and served as an introduction to the study of Roman law, perhaps also as an elementary guide in practice. It was frequently cited in the books.

${ }^{25}$ Rosellus compiled a collection of Flores Legum, Venice, 1572.

${ }^{26}$ Essays on Legal History (I913) paper on Two Ancient Brocards.

${ }^{27}$ Page 14.

29If the subject is exhausted, so also is the reader. Thus to take an example from the celebrated Farinacius; in qu. I2I, he lays down the Regula, follows it with nine ampliationes or extensions, and then with nine limitationes or exceptions, some with sub-limitations. No wonder that Matthaeu et Sanz, cont. 28, n. $44 \& \mathrm{n} .7 \mathrm{r}$, complains of another discussion of Farinacius that one's mind after diligent consideration of his "limitationes" cannot determine whether he affirms or denies the proposition. 
volume of the literature is indescribable. Swinburne in the Preface to his treatise on Wills, largely drawn from Civil law sources, says, that in his conceit, it is impossible for any one man to read over the hundredth part of their works, though living an hundred years, he did intend no other work. Then again we note an unfortunate absence of theoretical criticism or of historical discussion. Lord Stair in his Institutions, (the Scots law being in some measure derived from the works of the civilians) says, that "all their debate is a congestion of the contexts of the law; which exceedingly nauseates delicate engines, therein finding more work for the memory than judgment in taking up and retaining the lawgiver's will, rather than searching into his own reason." ${ }_{29}$ Yet even if we make due allowance for the progress of the scientific study of the law, the same faults appear in our present day legal treatises. How often are they mere digests of indigestible cases! Certainly, when we see, as we often do, in our books a doubtful question dismissed, after lengthy case-crammed foot notes, with the phrase "the trend of authority" or "the weight of modern decisions" seems to be \&c., we may well be reminded of the ancient reverence for the communis opinio. Some, however, of these old authors possessed the scientific temperament coupled with literary ability, such as, to mention only one at this time, Matthaeu et Sanz in his Controversiae. So in the Common law, the fruitful scientific treatises are rare. There are not many books on our shelves like Stephen on Pleading, Story on Equity Pleading, Holmes on the Common Law, and Wigmore on Evidence. Yet this is not surprising. Most law books are intended for the busy practitioner, who is not looking for a theoretical discussion of the subject, but for a precedent that will fit the case which he is soon to argue. An authoritative case in point saves both counsel and court

"Stair, [13]. Sir Edward Coke in the Proeme to the and Institute in speaking of the glosses, interpretations, and commentaries on the texts of the Civil law, all written by Doctors of equal authority, said that so many diversities of opinion rather increase than resolve doubts. But he went a little too far in extolling the certainty of the Common Law as the mother and nurse of repose and quietness. 
much labor in argument and decision; and this is right enough, for such is the object of reporting cases.

Another characteristic common to our own writings and to these civil lawyers is the quotation of authorities evidently at second hand. The same bunch of familiar citations appears over and over again, even in the same order, each subsequent writer being added in turn as an additional "authority," even if he did nothing more than copy what had already been written, and add his own name to it. This is what Burton in the Anatomy of Melancholy called pouring out of one bottle into another. There is also room for suspicion, that some of the writers did not disdain the time honored device of availing themselves of the labors of other less distinguished men. The life of no one man would seem, indeed, to suffice for the production of these Gargantuan folios of decisiones, consilia, quaestiones and tractatus, published under a single name, ${ }^{30}$ and here again we are not without modern instances.

In addition to their tedious verbosity and their excessive regard for mere authority without sufficient heed to the underlying principles of the law, the works of these old writers exhibit another serious defect, the scarcity of clear definition, a defect that to some extent may perhaps be attributed both to the liberality accorded to judicial discretion and to the absence of the jury from their legal procedure. Where questions of fact are decided by one division of the court and questions of law by another, exact definition is imperative; where however the judge exercises both functions, such definition becomes if not merely unnecessary, at least, an impediment to speedy decision. It may not be surprising that it is sometimes difficult to extract from the authorities a clear cut statement of legal distinctions. ${ }^{31}$

The great merit of these writers, however, lay in the fact, that they adapted the principles of the Justinianean 30The voluminous works of Farinacius for example are comprised in fifteen
folio volumes.

"1For example, the important classification of delicts as levia, atrocia, atrociora and atrocissima, is discussed by Farinacius qu. 18 and he concludes in $n .62$ and $n .92$, that the whole matter rests in the arbitrium of the judge after consideration of all the characteristics (qualitates) of the act committed. 
Corpus and the doctrines of their predecessors to the actual conditions of their own times, and infused new life into the older law. They performed in short the same functions which Sohm ascribes to the earlier commentators, ${ }^{32}$ who in like manner and in their day correlated and connected the old Roman law, the Canon law, the Statute law of the cities of Italy and the various local customs, thus producing by a process of fusion, a general common law the influence of which, extending beyond Italy was carried into other countries and permeated their jurisprudence.

It may be asked what benefits may be derived by the common lawyer from these antiquated writers? Let us assume that the inquiry does not refer merely to the advantage of an acquaintance with the older law of Rome, so often recommended and so seldom pursued in this country at least, but to the study of the more modern development of the Civil Law, which has been so briefly mentioned. What is the good of it? The question is not inspiring, but is natural enough in these days when everything that is not "practical" or "vocational" is by modern progressives, so called, only fit to be thrown into the dust bin.

But these studies are by no means to be disparaged. In the first place, it is at least becoming to a lawyer to known something of the great system of law under which the most important continental countries developed and flourished for so many centuries, and which forms the general basis of the present jurisprudence of the majority of civilized mankind. ${ }^{33}$ And we may learn, moreover, a lesson of humility, when we contrast the growth of the common law in its rude stages with that contemporary and more highly developed system which the common lawyer affects to despise. ${ }^{34}$ And

32Sohm's Institutes, Trans, Ledlie, 145.

33The reader is earnestly recommended to purchase a copy of David Murray's Lawyers' Merriments, Glasgow, 1912, where he will find an interesting and entertaining account of the Medieval law and lawyers.

${ }^{34}$ As Munroe Smith says of the study of the older Roman legal history, "We may thus better appreciate the true character of English legal history as an independent development. Furnished with a knowledge of the Roman law and of its development, the English investigator will more accurately gauge by comparison the excellencies and the defects of the English law." 4 Columbia Law Review. 
we may also learn to appreciate much better than in any other way, the history of Continental Europe, stabilized through its changing and shifting political and social crises by that wonderful continuity of legal theory and practice. Thus, we may note throughout our reading the profound influence of the Church on politics and society, the working of the Inquisition, the interlocking of ecclesiastical and secular jurisdiction, the growth of the medieval doctrine of the Divine Right of Kings, and the theories of natural rights. These medieval lawyers were men of great ability and learning. The professions of the Church and the Law attracted the brightest and most ambitious minds, powerful in analysis and trained in the logical studies of their day, and their conclusions profoundly affected the history of the world.

To pass to things more practical we may examine in these old law books the germs of International $\mathrm{Law}^{35}$ and of the Conflict of Laws. ${ }^{36}$

The student of Comparative Law will be interested in the theories of Equity, ${ }^{37}$ Criminal law and Evidence, ${ }^{38}$ in-

${ }^{36} \mathrm{Many}$ of the postmedieval authors drew largely not only from the Justinianean law, but from the later writers, whose labors in this way have entered into the modern books. See for example Richard Zouch, Jus et Judicium Fecialis; Samuel Rachel, de Jure Naturae et Gentium; Balthazar Ayala, de Jure et Officiis Bellicis, all published with translations by the Carnegie Institution.

${ }^{36} \mathrm{~J}$. $\mathrm{H}$. Beale of Harvard has published a translation of some portions of Bartolus on the Conflict of Laws; the later Italian law books contain much material for an elaborate treatise. Octavius Caracciolus published a Tractatus de fori privilegiatorum remissione, Palermo, I641. Huberus de Conflictu Legum was quoted by Lord Mansfield in Holman v. Johnson, I Cowper 34I, who said he was very glad the old books had been looked into. See also Robinson vs. Bland, I W. Blackstone, 256. I cannot forbear adding a reference to Farinacius qu. 7, n. 7 , who discusses the view of Bartolus and others, that a thief can be punished in the place where he is found with the stolen goods, although that is neither the place of the theft, or of his origin or domicil. Farinacius disagrees with this, and then asks what shall be done with the thief? Shall he be remitted (i. e., extradited) to another court of competent jurisdiction according to the opinion of Covarruvias and others? He concludes that the thief should be ejected from the place where he was captured and discharged in freedom. Says Dogberry, "the most peaceable way for you, if you do take a thief, is to let him show himself what he is, and steal-out of your company."

${ }^{37}$ Maine's Ancient Law (Ch. 3) refers briefly to the influence of the writings of the later Dutch jurists. See also Spence, Equitable Jurisdiction and Scrutton, Influence of Roman Law, on this subject. Julius Caesar Calvinus in his Tractatus de Aequitate assimilates "equitas" to "naturalis ratio" as well as "emendatio legis ex ea parte qua deficit ob universale," the Aristotelian definition.

${ }^{38}$ e. g., Josephus Mascardus de Probationibus, Jacobus Menochius, de Praesumptionibus. 
cluding procedure by torture, ${ }^{39}$ which was so universally employed, and of Witchcraft, which darkens so many pages. of medieval history. And of especial interest to us are the sources from which the common law derived, directly or indirectly, so much of its material on the subjects of commercial law and bankruptcy, of admiralty and maritime law,40 and of Legal Medicine,11 of easements ${ }^{42}$ and of testa- . mentary law. Each of these subjects deserves extended treatment, but I shall only briefly emphasize the last, and recall to the reader's memory Swinburne on Wills, asking him to observe from the marginal references how copiously the author has drawn not only from the Digest and Code with the Glosses and from Bartolus, Jason, Paulus Castrensis and other commentators, but also from the later writers.

${ }^{39}$ The books treating of torture are very numerous, e. g., Christophorus. Crusius, de Tortura; Hippolytus de Marsiliis, de Quaestionibus; Joannes Zangerius, de Quaestionibus, are among the most complete. The collection of Tractatus Criminales by Zilettus includes Brunus, Blanchus, Ghirlandus and others. Paulus Zacchias contains much in his Quaestiones Medico Legales; M. A. Bassanus, Aegidius Bossius, Flaminius Chartarius and Farinacius, and, indeed, all the writers on Criminal law treat largely on this subject. See De Sarno's Praxis with Scoppa's notes; Raynaldus Obser. 34, Scanarolus, de Visitatione Carceratorum; and Nicolinus Praxis Judiciaria. In English, Henry C. Lea on Superstition and Force.

40"And even as the roundness of the Globe of the World is composed of the Earth and Waters; so the body of Lex Mercatoria is made and framed by the Merchants Customes, and the Sea Lawes, which are involved together as theseas and earth." Gerard Malynes, Lex Mercatoria, Preface. Malynes does not cite authorities in his book, but they must have been found by him in the current continental treatises. See W. Mitchell, Law Merchant, and as to Early History of Bankruptcy Law, article by Louis E. Levinthal, 66 Univ. of Penna. Law Review. 223.

41The earliest writer appears to be Fortunatus Fidelis of Florence, Derelationibus medicorum, Palermo, 1598, republished 1602, and at Leipsic, 1674, followed by Paulus Zacchias (1584-1659), whose great work Quaestiones MedicoLegales was published at Rome, I62I-1635, the best edition by Horstius, Nuremburg, 1726. To these should be added Michael Bernhardus Valentinus of Hesse Darmstadt (1657-I729), Corpus Juris Medico-Legale, Frankfort a. m. I70I, later edition, 1722 . Paris \& Fonblanque's Introduction to Medical Jurisprudence, 1823, and Beck's Elements of Medical Jurisprudence, 1823, IIth ed. I860, contain interesting bibliographies and both learned works refer frequently. to the continental literature. J. S. Forsyth, Synopsis of Modern Medical Jurisprudence styles the treatise of Zacchias "a most valuable record of facts and a permanent monument of the talents of the author," and that of Valentinus "a complete and extensive retrospect of the opinions and decisions of preceding writers." See also Goelicke Introductio in historiam \&c., 1723, E. E. Richter, Digesta Medica, Leipsiz \& Bautzen, I73I, and Fr. Hargrave Jurisconsult Exercitations, vol. 3, p. 4I6, who cites Zacchias's "famous Quaestiones" on a point of filiation.

${ }^{42}$ Bartholomaeus Cepolla de Servitutibus. 
such as Julius Clarus, de Testamentis; Didacus Covarruvias; Franciscus Mantica, de conjecturis ultimarum voluntatum; Simo de Praetis, de interpretatione ultimarum voluntatum; Josephus Mascardus, de Probationibus, Jacobus Menochius, de Arbitrariis and de Praesumptionibus; Joannes Oldendorpius; Hippolytus de Marsilliis; Aymon Cravetta; Andreas Tiraquellus, ${ }^{43}$ and scores of others whom it would be tedious here to mention. Many of the opinions and decisions recorded by these writers, embodied by Swinburne in his classical treatise, and after him by Godolphin in his Orphans' Legacy, have passed into our Law, and even at this day we may obtain some profit from consulting them.

We children of the Common Law may also derive a general benefit from these comparative studies, for it will be found that the methods of legal reasoning are well nigh universal; the materials of these lawyers and judges were very different from ours, yet they were handled in much the same way, and it is interesting to observe, that in many concrete instances they arrived at the same results by diverse paths. ${ }^{44}$

In conclusion, one who is interested in the study of languages, grammar and philology may glean both entertainment and profit by a perusal of these writers. Their works, are, of course, written in Latin of that familiar and colloquial kind, which was not only used by the lawyers of the time, but was the ordinary vehicle of all learning. It is not always easy reading for those accustomed only to classical Latin, and even those, who have made some acquaintance with the medieval Latin, will experience some diffi.culty. ${ }^{45}$ While the basis of this vulgar Latin was, of course, the classical Latin of Cicero and Caesar, it was greatly modified by the vocabularies of the learned professions of the Law

${ }^{43}$ André Tiraqueau, the friend of Rabelais, whose most important work was his Tractatus de legibus connubialibus.

"W. W. Buckland in his excellent treatise on Equity in Roman Law makes some valuable comments on this subject, with special reference however to the Justinianean law.

${ }^{45}$ Yet their Latin was not as bad as that referred to by Mr. Herman Cohen in his Origins of the English Bar, 36 L. Q. R. 277, who wittily says, "the I.atin is so bad that one must be singularly ignorant of that language to understand it at all." 
and the Church, and corrupted by the idioms of the vernacular languages as they were assuming their modern forms. ${ }^{46}$ In the so called Romance countries, Italy, France and Spain, this lingua mixta never lost its Roman tradition, and was. almost the mother tongue of educated people, while in Germany and in England, it was a language that was acquired with greater effort. Even in England, Francis Bacon thought that Latin would always be the language of all learning and composed in it his most important books, or those that he thought the most important. His forecast was wrong; but if Latin had retained its position as a practical universal language, the benefit to mankind would have been enormous. As long, however, as Latin retained its hold upon the educated world, the lawyers, at least, reaped a great benefit, for they had immediate and easy access to all the law books of ${ }^{-}$ all the countries of Europe, that were founded on the Roman Law. The present day advocates of a universal language, like Volapuk and Esperanto, might well consider the advisability of reviving the study and use of the vulgar Latin. ${ }^{47}$

The student, however, will be troubled by the absencein lexicons of the neologisms and barbarisms of this coloquial law Latin, and of the technical terms of the medieval: law. DuCange, of course, is very helpful, but this great glossary, so far as the law is concerned, includes little beyond the Canon law in which its compilers were especially interested. The smaller handbook of D'Arnis contains much that is not found in DuCange, and help may be obtained. from some of the older Latin-English dictionaries, ${ }^{48}$ but in many instances the meaning of the words can only be discovered by reading and a comparison of the texts. ${ }^{49}$

"See some interesting comments by Henry Osborn Taylor, The Medieval:

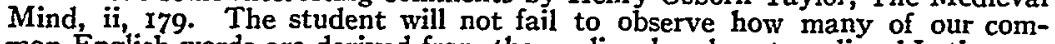
mon English words are derived from the medieval and post medieval Latin. ${ }^{47}$ See articles by Prof. Louis John Paetow on Latin as a Universal Language, 15 Classical Journal 340; and on The Future of Latin, 14 Classical Weekly 17. 18Such as Bailey's edition of Facciolati \& Forcellini, Ainsworth, Cambridge
Dictionary \&c.

49The technical law lexicons such as Barnabas Brissonius, Pardulphus Parteius, and Joannes Calvinus are not very satisfactory in this respect to the . modern reader. 
The limits of this article would prevent any remarks upon the peculiarities of syntax, diction \&c, of this law Latin which might well form the subject of a volume by a competent grammarian. I might, however, by way of warning to the classical student, adapt the advice said to have been given by an English Bishop to his clergy, not to read the New Testament in the original for fear of corrupting their classical scholarship. Certainly the perusal of the books here mentioned does not tend to the improvement of a classical style, and after ore reads some of these old Tractatus and Consilia, the pages of Cicero seem strange indeed.

But enough. As Sir Edward Coke observed with one of his delightful mixed metaphors, "This little taste shall give a light to the diligent reader."

City Hall, Philadelphia John Marshall Gest

${ }^{\circ}$ Co. Litt. $290 a$. 